\title{
FOS Family Gene
}

National Cancer Institute

\section{Source}

National Cancer Institute. FOS Family Gene. NCI Thesaurus. Code C17451.

FOS Family Genes encode nuclear leucine zipper FOS Family Proteins (FOS, FOSB, FOSL1, and FOSL2) that can dimerize with JUN Family proteins and bind DNA as the AP-1

transcription factor complex to regulate transcription in cell proliferation, differentiation, and transformation. $(\mathrm{NCl})$ 